\title{
A new, rare and distinctive species of Panorthoptera (Insecta, Archaeorthoptera) from the Upper Carboniferous of Xiaheyan (Ningxia, China)
}

\author{
Jun-Jie Gu ${ }^{1}$, Olivier Béthoux ${ }^{2,4}$, and Dong Ren $^{3}$ \\ ${ }^{1}$ College of Biological Sciences and Engineering, North Minzu University, 204 Wenchangbeijie, Xixia District, \\ Yinchuan, 750021, China \\ ${ }^{2}$ Sorbonne Universités, UPMC (Paris 6), MNHN, CNRS, UMR 7207, Centre de recherche sur la Paléobiodiversité et les \\ Paléoenvironnements (CR2P), Paris, France \\ ${ }^{3}$ College of Life Sciences, Capital Normal University, 105 Xisanhuanbeilu, Haidian District, Beijing, 100048, China \\ ${ }^{4}$ Muséum National d'Histoire Naturelle, 57 rue Cuvier, CP38, 75005, Paris, France \\ Correspondence to: Dong Ren (rendong@mail.cnu.edu.cn)
}

Received: 9 May 2017 - Revised: 4 September 2017 - Accepted: 22 September 2017 - Published: 7 November 2017

\begin{abstract}
The Xiaheyan locality is providing abundant material on one of the earliest insect faunas. The most common species are comparatively remote relatives of Orthoptera (grasshoppers, crickets and katydids), belonging to the Archaeorthoptera nec Panorthoptera (the latter including crown Orthoptera). We establish the genus Sinogerarus gen. nov. to accommodate a new, rare species, $S$. pectinatus spec. nov., which can be conclusively assigned to Panorthoptera. It therefore represents the second occurrence of the group at this locality. The new species displays a distinctive combination of character states, adding to the knowledge of a number of Upper Carboniferous Panorthoptera whose relationships are poorly understood.
\end{abstract}

\section{Introduction}

The Xiaheyan locality (Ningxia, China) is a Late Carboniferous outcrop providing insects in very large abundance, i.e. at least an order of magnitude above known contemporaneous localities. Several of the described species are represented by tens of specimens, including some with both forewings preserved attached to the pterothorax. This exceptional material allowed solid inferences on wing venation intra-specific variability in various insect lineages (e.g. Béthoux et al., 2011, 2012b; Cui et al., 2011; Gu et al., 2011; Li et al., 2013; Pecharová et al., 2015). Moreover, both males and females were identified for two species (Du et al., 2017; Pecharová et al., 2015), one of them, a relative of grasshoppers, crickets and katydids (Orthoptera), displaying a significant femalebiased sexual size dimorphism. Such data are essential to better delimit early insect species, a chronic issue, and in particular for those species with no relevant extant counterparts (Béthoux, 2009).

The current overview of the insect fauna (or, at least, the taphocoenosis) suggests that it is dominated by stem lineages of Orthoptera. Most of the species described to date are comparatively remote relatives of Orthoptera (Archaeorthoptera nec Panorthoptera). Panorthoptera, a taxon including species more closely related to crown Orthoptera, are represented by a single species, Heterologus duyiwuer Béthoux, $\mathrm{Gu}$ and Ren, 2012a, with a single forewing described. Herein we describe the second species of Panorthoptera from this fauna, also documented by a single forewing, which displays a unique combination of character states.

\section{Material and methods}

The studied specimen is housed at the Key Lab of Insect Evolution and Environmental Changes, College of Life Sciences, Capital Normal University, Beijing, China (CNU). It was collected from the locality near Xiaheyan village, Zhongwei City, Ningxia Hui Autonomous Region, China. The exact layer from which it was collected was not documented. 
Previous studies suggested a Namurian B/C/early Bashkirian age for the whole locality (Lu et al., 2002; Zhang et al., 2013), but ongoing studies (Trümper et al., 2017) are revealing that the locality is probably younger. A Moscovian age is more likely for the higher insect-bearing horizons.

A draft drawing was produced using a Leica MZ12.5 dissecting microscope equipped with a drawing tube (Leica, Wetzlar, Germany). It was finalized using Adobe Illustrator CS6 (Adobe Systems, San Jose, CA, USA). The photograph was taken using a digital camera Canon 5D Mark III (Canon, Tokyo, Japan), coupled to a Canon MP-E $65 \mathrm{~mm}$ macro lens equipped with a polarizing filter. The resulting photograph was optimized using Adobe Photoshop CS6.

We follow the serial insect wing venation ground pattern (Lameere, 1922, 1923). The corresponding wing venation nomenclature is repeated for convenience: $\mathrm{ScP}$, posterior subcosta; $\mathrm{R}$, radius; $\mathrm{RA}$, anterior radius; $\mathrm{RP}$, posterior radius; $\mathrm{M}$, media; MA, anterior media; MP, posterior media; $\mathrm{Cu}$, cubitus; $\mathrm{CuA}$, anterior cubitus (indicated by an asterisk in Fig. 1); $\mathrm{CuP}$, posterior cubitus; $\mathrm{CuPa}$, anterior branch of $\mathrm{CuP}$; $\mathrm{CuPa} \alpha$, anterior branch of $\mathrm{CuPa} ; \mathrm{CuPa} \beta$, posterior branch of $\mathrm{CuPa} ; \mathrm{CuPb}$, posterior branch of $\mathrm{CuP}$; $\mathrm{AA}$, anterior analis. Based on this ground pattern we follow topographic homology conjectures proposed by Béthoux and Nel $(2002,2001)$ for total Orthoptera (see Du et al., 2017, for references on alternative proposals and the associated discussion).

\section{Description of new taxa}

Taxon Archaeorthoptera Bethoux and Nel, 2002

Taxon Panorthoptera Crampton, 1928 (sensu Béthoux and Nel, 2002)

Sinogerarus Gu, Béthoux and Ren gen. nov.

(urn:1sid:zoobank.org:act:D42326AA-4A4A-4222-

A2B2-7591FA91CF78) (The registration date is 27 September 2017.)

Type species: Sinogerarus pectinatus spec. nov.

Gender: Masculine.

Etymology: A combination of "Sino", referring to the geographic origin of the holotype, and Gerarus, a genus name used for species sharing similarities with the new one.

Diagnosis: By monotypy, as for the type species.

Sinogerarus pectinatus Gu, Béthoux and Ren spec. nov.

(urn:1sid:zoobank.org:act:008B9E61-F8FC-429F-

A319-FD5914220387) (The registration date is 27

September 2017.)

(Fig. 1)
Material: Holotype only, CNU-NX1-343, deposited at the CNU.

Etymology: The species epithet derives from the Latin "pectinatus", referring to the regular branching patterns of $\mathrm{RP}, \mathrm{MP}$ and $\mathrm{CuA}+\mathrm{CuPa} \alpha$, all posteriorly pectinate.

Diagnosis: Forewing: RP regularly posteriorly pectinate; lack of connection of RP with MA (or the anterior branch of $\mathrm{M}$ ); $\mathrm{M}$ (emerging from $\mathrm{M}+\mathrm{CuA}$ ) simple for a long distance (first fork at ca. the second fifth of $\mathrm{M}$ length); MP regularly posteriorly pectinate; $\mathrm{CuA}+\mathrm{CuPa} \alpha$ straight, regularly posteriorly pectinate; $\mathrm{CuPa} \beta$ simple; $\mathrm{CuPb}$ forked, distally; cross-venation reticulated in most areas, with loosely organized pseudo-veins in the distal part of the areas between RP branches.

Description: Holotype specimen (CNU-NX1-343): Isolated forewing, veins elevation not evident (as a consequence it cannot be determined whether it is a right or a left wing); base, most of anterior wing margin and apical area missing; wing apparently disrupted just basal of the first RP fork (putative correspondences indicated by double-headed arrows in Fig. 1); preserved length $23.6 \mathrm{~mm}$, estimated length about $32 \mathrm{~mm}$, width about $8 \mathrm{~mm}$; area between $\mathrm{ScP}$ and R/RA narrow, with straight and distinct cross-veins; RA simple in preserved parts; RP posteriorly pectinate, with five branches preserved, all simple (as preserved); M simple for $8.0 \mathrm{~mm}$ before it forks into MA and MP (just basal of the first RP fork); MA simple; MP posteriorly pectinate, with three branches reaching posterior wing margin, all simple; free $\mathrm{CuA}$ (emerging from $\mathrm{M}+\mathrm{CuA}$ ) $1.0 \mathrm{~mm}$ long, fusing with $\mathrm{CuPa} \alpha$; $\mathrm{CuA}+\mathrm{CuPa} \alpha$ straight, simple for $2.4 \mathrm{~mm}$, then posteriorly pectinate, with a total of six branches reaching the posterior wing margin, all simple; $\mathrm{CuPa}$ forked (into $\mathrm{CuPa} \alpha$ and $\mathrm{CuPa} \beta$ ) shortly before the origin of free $\mathrm{CuA}$; area between $\mathrm{M}$ and $\mathrm{CuA}+\mathrm{CuPa} \alpha$ broad, with up to four rows of cells; $\mathrm{CuPb}$ forked distally, with two terminal branches; most areas of preserved forewing covered by a network of cross-veins, loosely organized in pseudo-veins in the distal part of the areas between RP branches.

Locality and horizon: Xiaheyan village, Zhongwei City, Ningxia, China; Tupo Formation; Namurian B/C?, Upper Carboniferous.

Discussion: The new specimen can be assigned to Archaeorthoptera as it exhibits the defining character state of this taxon (formally defined in Béthoux, 2007), namely a fusion of $\mathrm{CuA}$ (diverging from $\mathrm{M}+\mathrm{CuA}$ ) with the anterior branch of $\mathrm{CuP}$. The occurrence of a fork of $\mathrm{CuPa}$ basal to the fusion with $\mathrm{CuA}$ (itself emerging from $\mathrm{M}+\mathrm{CuA}$ ) indicates that, within Archaeorthoptera, it belongs to the clade Panorthoptera (not formally defined; see diagnosis in Béthoux and Nel, 2002). This clade includes Orthoptera 

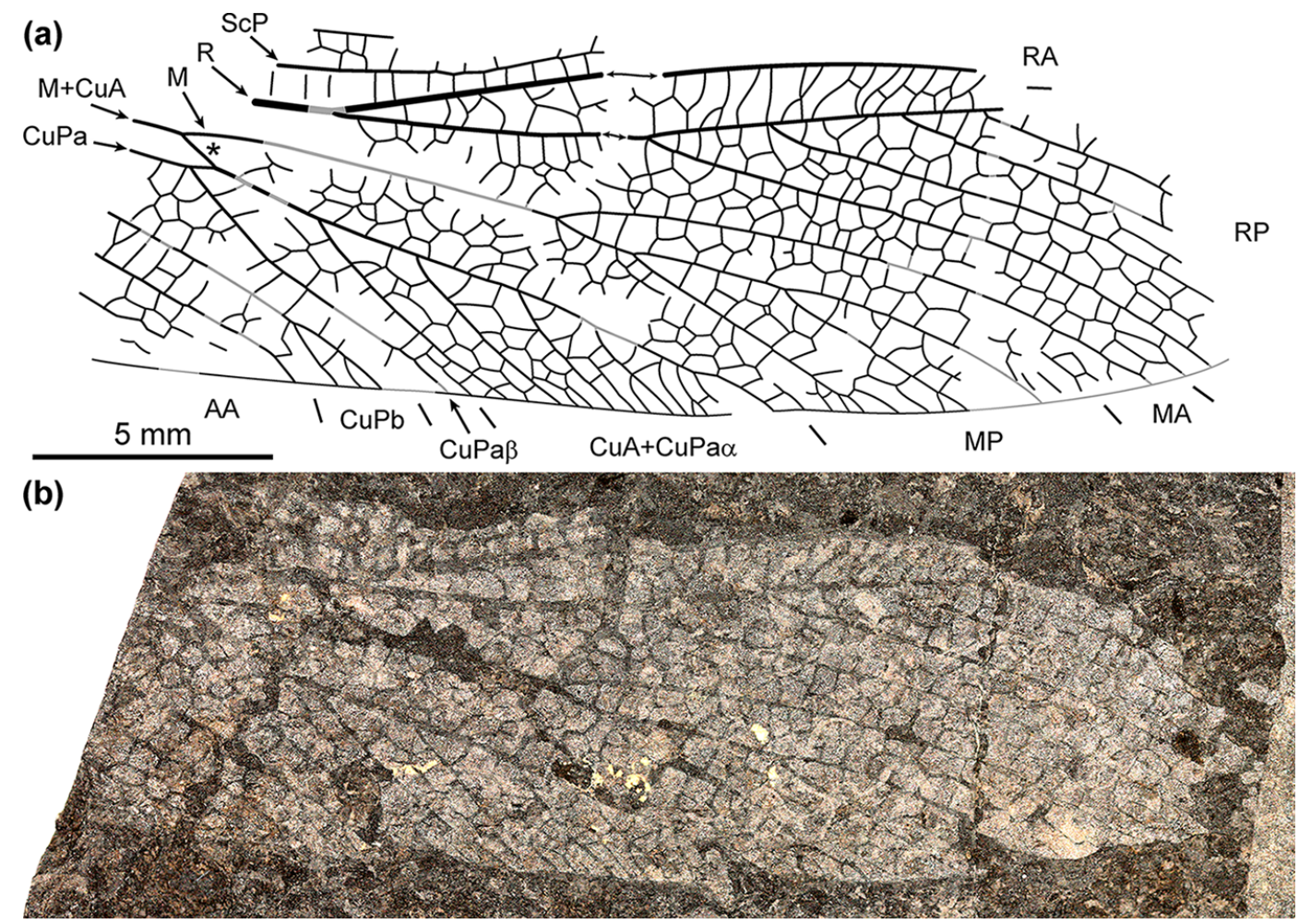

Figure 1. Sinogerarus pectinatus gen. and spec. nov., holotype (CNU-NX1-343), habitus: (a) interpretative drawing and (b) photograph (flipped horizontally). See text for symbols and abbreviations.

and their closest fossil relatives, such as "geraridaeans" and "oedischioideans", whose reciprocal relationships are not evident (the supposed "hemipteroid" affinities of the former were challenged by Béthoux and Briggs, 2008), and a number of distinctive species, such as $H$. duyiwuer and Bruaylogus magnificus Coty, Háva, Prokop, Roques and Nel, 2014. The Caloneurodea, an extinct Palaeozoic order, are also considered close relatives of Orthoptera (Béthoux et al., 2004). As argued below, the new specimen shares similarities with many of these taxa but cannot be conclusively affiliated to any.

Most "geraridaeans" and all "oedischioideans" display a fork of M located shortly after the point of divergence of $\mathrm{M}$ from M + CuA (Béthoux and Nel, 2003; Carpenter, 1992; Gorochov, 1995; Kukalová-Peck and Brauckmann, 1992; Sharov, 1968, 1971; Zessin, 2009), unlike the new specimen, in which $\mathrm{M}$ is simple for ca. two-fifths of its length. Among "geraridaeans", Gerarus fischeri (Brongniart, 1885) (revised in Béthoux and Nel, 2003) and Osnogerarus trecwithiensis Kukalová-Peck and Brauckmann, 1992 (revised in Brauckmann and Herd, 2006 - including a drawing by O. Béthoux) both display a comparatively distal first fork of M. Yet the new specimen can be distinguished from both species (and most "oedischioideans") owing to the lack of "connection" (actual fusion or connection via a short cross-vein) between RP and MA. Moreover, cross-venation is denser in G. fish- eri and $O$. trecwithiensis and does not tend to form intercalary pseudo-veins in the apical area. Finally, the forked $\mathrm{CuPb}$ precludes an assignment of the new specimen to the "oedischioideans", in which this vein is always simple.

The very regular branching pattern of RP and the apparent distal fork of $\mathrm{M}$ are reminiscent of the Caloneurodea, but (1) according to Béthoux et al. (2004) the apparent distal fork of $\mathrm{M}$ in Caloneurodea is actually the first fork of MA, the first fork of $\mathrm{M}$ being super-imposed with the $\mathrm{M} / \mathrm{CuA}$ fork (there is no evidence of such fusion in the new specimen) and (2) in Caloneurodea $\mathrm{CuA}+\mathrm{CuPa} \alpha$ (actually $\mathrm{MP}+\mathrm{CuA}+$ $\mathrm{CuPa} \alpha$ ) is simple (if with an anterior branch, it then corresponds to MP; $\mathrm{CuA}+\mathrm{CuPa} \alpha$ is richly branched in the new specimen). Note that Spiculum mendicum Brauckmann and Herd, 2006 is a candidate Caloneurodea. Affinities with this order can be excluded.

Among the "unplaced" Panorthoptera species, B. magnificus has a fusion of $\mathrm{CuPa} \alpha$ located opposite the point of divergence of $\mathrm{M}$ and $\mathrm{CuA}$. In other words, there is no free part of $\mathrm{CuA}$ emerging from $\mathrm{M}+\mathrm{CuA}$, unlike in the new specimen (asterisk in Fig. 1). Several other features (cross-venation, branching pattern of RP, etc.) allow the new specimen to be differentiated from B. magnificus. After its late branching of $\mathrm{M}$, the new specimen resembles Heterologus langfordorum Carpenter, 1944, but this species does not display the regular branching pattern of RP, MP and $\mathrm{CuA}+\mathrm{CuPa} \alpha$; it also has a 
simple $\mathrm{CuPb}$ (forked distally in the new specimen). The new specimen maybe shares the most numerous similarities with $H$. duyiwuer (from the same locality; provisionally assigned to the genus Heterologus in the original description), including the distal first fork of $\mathrm{M}$ and the forked $\mathrm{CuPb}$. The most conspicuous difference regards the cross-venation (reticulation occurs only in the distal-most areas in the forewing in $H$. duyiwuer). Also, branches of $\mathrm{CuA}+\mathrm{CuPa} \alpha$ are emitted regularly in the new specimen, while in $H$. duyiwuer there is a long distance between the point of divergence of the first and second posterior branches. Based on the available data, the new specimen has a forewing more elongate than that of $H$. duyiwuer. A number of additional species which are putative stem Orthoptera (see Brauckmann and Herd, 2006) are documented based on very fragmentary material and therefore will not be discussed. We conclude that erecting a new genus and a new species is justified.

Sinogerarus pectinatus displays a combination of character states whose polarities are difficult to assess due to (1) the scarcity of non-"geraridaean" and non-"oedischioidean" Panorthoptera material and (2) the lack of identified immediate sister group of Panorthoptera. Even though it remains perplexing in some respects, the newly described species adds to the knowledge of a poorly documented set of Upper Carboniferous insects.

Data availability. No data sets were used in this article.

Competing interests. The authors declare that they have no conflict of interest.

Acknowledgements. We thank the anonymous reviewers for their useful comments. We thank the numerous students who over the years contributed to fieldwork at Xiaheyan. This research is supported by the National Natural Science Foundation of China (nos. 31360525, 31730087, 41688103), Program for Changjiang Scholars and Innovative Research Team in University (IRT17R75).

Edited by: Johannes Müller

Reviewed by: two anonymous referees

\section{References}

Béthoux, O.: Cladotypic taxonomy applied: titanopterans are orthopterans, Arth. Syst. Phyl., 65, 135-156, 2007.

Béthoux, O.: Gaps and nodes between fossil and extant insects, Syst. Ent., 34, 599-609, https://doi.org/10.1111/j.13653113.2009.00484.x, 2009.

Béthoux, O. and Briggs, D. E. G.: How Gerarus lost its head: stemgroup Orthoptera and Paraneoptera revisited, Syst. Ent., 33, 529547, https://doi.org/10.1111/j.1365-3113.2008.00419.x, 2008.
Béthoux, O. and Nel, A.: Venation pattern of Orthoptera, J. Orthopt. Res., 10, 195-198, https://doi.org/10.1665/10826467(2001)010[0195:VPOO]2.0.CO;2, 2001.

Béthoux, O. and Nel, A.: Venation pattern and revision of Orthoptera sensu nov. and sister groups. Phylogeny of Palaeozoic and Mesozoic Orthoptera sensu nov., Zootaxa, 96, 1-88, https://doi.org/10.11646/zootaxa.96.1.1, 2002.

Béthoux, O. and Nel, A.: Wing venation morphology and variability of Gerarus fischeri (Brongniart, 1885) sensu Burnham (Panorthoptera; Upper Carboniferous, Commentry, France), with inferences on flight performances, Org. Div. Evol., 3, 173-183, https://doi.org/10.1078/1439-6092-00070, 2003.

Béthoux, O., Nel, A., and Lapeyrie, J.: The extinct order Caloneurodea (Insecta, Pterygota, Panorthoptera): wing venation, systematics, and phylogenetic relationships, Ann. Zool., 54, 289318, 2004.

Béthoux, O., Cui, Y., Kondratieff, B., Stark, B., and Ren, D.: At last, a Pennsylvanian stem-stonefly (Plecoptera) discovered, BMC Evol. Biol., 11, 248, https://doi.org/10.1186/1471-2148-11-248, 2011.

Béthoux, O., Gu, J.-j., and Ren, D.: A new Upper Carboniferous stem-orthopteran (Insecta) from Ningxia (China), Insect Sci., 19, 153-158, https://doi.org/10.1111/j.1744-7917.2011.01468.x, 2012a.

Béthoux, O., Gu, J., Yue, Y., and Ren, D.: Miamia maimai n. sp., a new Pennsylvanian stem-orthopteran insect, and a case study on the application of cladotypic nomenclature, Foss. Rec., 15, 103-113, https://doi.org/10.1002/mmng.201200008, 2012b.

Brauckmann, C. and Herd, K. J.: Insekten-Funde aus dem Westfalium D (Ober-Karbon) des Piesberges bei Osnabrück (Deutschland). Teil 2: Neoptera, Osnabrücker nat. Mitt., 30/31 (for 2005), 19-65, 2006.

Brongniart, C.: Les Insectes fossiles des terrains primaires. Coup d'oeil rapide sur la faune entomologique des terrains paléozoïques, Bull. Soc. Amis Sci. nat. Rouen, 1885, 50-68, https://doi.org/10.5962/bhl.title.36372, 1885.

Carpenter, F. M.: Carboniferous insects from the vicinity of Mazon Creek, Illinois, Illinois State Mus. Sci. Pap., 3, 1-20, 1944.

Carpenter, F. M.: Superclass Hexapoda. In: Treatise on Invertebrate Paleontology, edited by: Kaesler, R. L., The Geological Society of America and the University of Kansas, Boulder, 1992.

Coty, D., Háva, J., Prokop, J., Roques, P., and Nel, A.: New archaeorthopteran insects from the Late Carboniferous of the Nord and Pas-de-Calais basins in northern France (Insecta: Cnemidolestodea, Panorthoptera), Zootaxa, 3878, 462-470, https://doi.org/10.11646/zootaxa.3878.5.4, 2014.

Crampton, G. C.: The grouping of the insect orders and their lines of descent, The Entomologist, 61, 82-85, 1928.

Cui, Y., Béthoux, O., and Ren, D.: Intraindividual variability in Sinonamuropteridae forewing venation (Grylloblattida; Late Carboniferous): taxonomic and nomenclatural implications, Syst. Ent., 36, 44-56, https://doi.org/10.1111/j.13653113.2010.00545.x, 2011.

Du, S., Béthoux, O., Gu, J., and Ren, D.: Protomiamia yangi gen. et sp. nov. (Early Pennsylvanian; Xiaheyan, China), a sexually dimorphic Palaeozoic stem-Orthoptera, J. Syst. Pal., 15, 193-204, https://doi.org/10.1080/14772019.2016.1154899, 2017. 
Gorochov, A. V.: System and evolution of the suborder Ensifera (Orthoptera). Part I, Proc. Zool. Inst. Russ. Acad. Sci., 260, 1224, 1995.

Gu, J., Béthoux, O., and Ren, D.: Longzhua loculata n. gen. and n. sp., one of the most completely documented Pennsylvanian Archaeorthoptera (Insecta; Ningxia, China), J. Pal., 85, 303-314, https://doi.org/10.1666/10-085.1, 2011.

Kukalová-Peck, J. and Brauckmann, C.: Most Paleozoic Protorthoptera are ancestral hemipteroids: major wing braces as clues to a new phylogeny of Neoptera (Insecta), Can. J. Zool., 70, 2452-2473, https://doi.org/10.1139/z92-330, 1992.

Lameere, A.: Sur la nervation alaire des insectes, Bull. Cl. Sci. Acad. Roy. Belg., 8, 138-149, 1922.

Lameere, A.: On the wing-venation of insects, Psyche, 30, 123-132, https://doi.org/10.1155/1923/16920, 1923.

Li, Y., Béthoux, O., Pang, H., and Ren, D.: Early Pennsylvanian Odonatoptera from the Xiaheyan locality (Ningxia, China): new material, taxa, and perspectives, Foss. Rec., 16, 117-139, https://doi.org/10.1002/mmng.201300006, 2013.

Lu, L., Fang, X., Ji, S., and Pang, Q.: A contribution to the knowledge of the Namurian in Ningxia, Acta Geosci. Sin., 23, 165$168,2002$.
Pecharová, M., Ren, D., and Prokop, J.: A new palaeodictyopteroid (Megasecoptera: Brodiopteridae) from the Early Pennsylvanian of northern China reveals unique morphological traits and intra-specific variability, Alcheringa, 39, 236-249, https://doi.org/10.1080/03115518.2015.993299, 2015.

Sharov, A. G.: Filogeniya orthopteroidnykh nasekomykh, Trudy Paleontol. inst. Akad. Nauk SSSR, 118, 1-216, 1968.

Sharov, A. G.: Phylogeny of the Orthopteroidea, Israel Program for Scientific Translations, Jerusalem, 1971.

Trümper, S., Schneider, J. W., Béthoux, O., Ren, D., and Linnemann, U. G.: Paper in preparation, 2017.

Zessin, W.: Ploetzgerarus krempieni n. gen. et sp. - eine neue Geraride (Insecta: Panorthoptera: Geraridae) aus dem Oberkarbon (Stephanium C) von Plötz bei Halle (Deutschland), Virgo, Mitt. Entomol. Ver. Mecklenburg, 13, 22-29, 2009.

Zhang, Z., Schneider, J. W., and Hong, Y.: The most ancient roach (Blattodea): a new genus and species from the earliest Late Carboniferous (Namurian) of China, with a discussion of the phylomorphogeny of early blattids, J. Syst. Pal., 11, 27-40, 2013, https://doi.org/10.1080/14772019.2011.634443. 